\title{
Antiferromagnetic Exchange Interactions. Part 1. Newly Reported Nickel(II) Complex of the Antiprine Schiff Base of 3-Formylsalicylic Acid
}

\author{
Ali Bayri ${ }^{1,2}$
}

ERRATUM TO: JOURNAL OF INORGANIC AND ORGANOMETALLIC POLYMERS AND MATERIALS DOI: 10.1007/s10904-006-9020-4

The submitted and accepted dates for this paper were inadvertently omitted. The dates are as follows:

Submitted September 27, 2005; accepted October 10, 2005

The online version of the original article can be found at http:// dx.doi.org/10.1007/s10904-006-9020-4

${ }^{1}$ Arts and Science Faculty, Department of Physics, Inonu University, Tr-44069, Malatya, Turkey.

2 To whom correspondence should be addressed.

E-mail: abayri@inonu.edu.tr 